\author{
Kari Hansen \\ Norges teknisk-naturvitenskapelige universitet (NTNU)
}

DOI: http://dx.doi.org/10.5617/adno.7925

\title{
Mesterlære i praksisveiledning i lærerutdanning: Individuell, relasjonell eller i praksisfelleskap? En studie av eksamenstekster
}

\begin{abstract}
Sammendrag
Hensikten med artikkelen er å undersøke hvordan deltakere i en videreutdanning for praksislærere i en videregående skole diskuterer muligheter og utfordringer i praksisopplæringen i sine eksamenstekster i lys av hovedtrekk fra teori om mesterlære. Som yrkesfaglærerutdanner, tidligere yrkesfaglærer og praksislærer, ønsker jeg å unders $\emptyset$ ke om og hvordan en praktisk kunnskapstradisjon, hvor modell-læring inngår, og som har sitt utgangspunkt i praksis og praksisfellesskap, preger diskusjonen om utfordringer og muligheter i dagens praksisopplæring (Nielsen \& Kvale, 1999a). Artikkelens utgangspunkt er 10 av 31 gruppebaserte eksamensbesvarelser fra en videreutdanning (7,5 studiepoeng) gjennomført ved én av NTNUs universitetsskoler i vårsemesteret 2016. I artikkelen besvares følgende problemstilling: Hvordan bruker praksislærerne hovedtrekk fra mesterlære i drøftinger av utfordringer og muligheter i praksisveiledning? Tematisk tekstanalyse av eksamensoppgavene (Widén, 2017) identifiserte tre hovedtrekk fra mesterlære i lærernes drøfting av organiseringen av praksisveiledning. Temaene er 1) Modell-læring, 2) Relasjonskompetanse, og 3) Praksisfellesskap. Praksislærernes forståelse knyttes til tre funn: 1) Praksislærerne ønsker å vise frem sin praksis for studentene. 2) Praksislærerens relasjonskompetanse og kommunikative kompetanse er grunnleggende viktig i rollen som modell-lærer. 3) Læring i praksisfellesskap - studentene lærer av flere praksislærere/mestere.
\end{abstract}

Nøkkelord: mesterlære, modell-læring, praksislærer, praksisfellesskap, relasjonskompetanse, praksisveiledning i lærerutdanning

\section{Apprenticeship in practice supervision in teacher education: Individual, relational or in community of practice? A study of exam texts}

\begin{abstract}
The purpose of the article is to investigate how participants in a course offered as further education for practice teachers in an upper secondary school discuss opportunities and challenges in the practice training in light of main features of the theory of apprenticeship. As a vocational teacher educator, former vocational teacher and practice teacher, I want to investigate whether and how a practical knowledge tradition, in which model-learning is included, and which is based on practice and communities of practice,
\end{abstract}


characterizes the discussion of challenges in today's practice training (Nielsen \& Kvale, 1999a). The article is based on 10 out of 31 group-based exam papers from a further education course ( 7.5 credits) completed at one of NTNU's university schools during the spring semester 2016. The article answers the following research question: How do the practice teachers use main features of apprenticeship in discussions of challenges and opportunities in practice supervision? The thematic text analysis of the exam papers (Widén, 2016) identified three main features from apprenticeship in the teachers' discussion of the organization of practice supervision. The themes are 1) Modellearning, 2) Relational competence, and 3) Community of practice. The practice teachers' reflection is linked to three findings: 1) The practice teachers want to showcase their practice to the students. 2) Relational competence and the practice teacher's communicative competence are fundamentally important in the role as a model teacher. 3) Practice in working communities - students learn from several practice teachers/ masters.

Keywords: apprenticeship, model-learning, practice teacher, community of practice, relational competence, practice supervision in teacher education

\section{Innledning}

Mesterlære er blitt kritisert for å fremme et reproduktivt syn på læring uten selvstendig kritisk refleksjon, og for at mesterlære innebærer imitasjon eller kopiering (Nielsen \& Kvale, 1999a). Virkeligheten i verkstedet er derimot preget av sosial interaksjon i arbeid. Mestrene møtes i verkstedet, med ulike roller. Den ene er frisørmester og lærerstudent under utdanning mot å bli yrkesfaglærer. Den andre er frisørmester, yrkesfaglærer og praksislærer i lærerutdanning. I det ene $\varnothing$ yeblikket blir praksislærerens undervisning gjenstand for observasjon, undring og diskusjon mens praksislæreren demonstrerer og gir råd om hvordan ulike didaktiske tilnærminger kan spilles ut i konteksten. I neste $\varnothing$ yeblikk byttes rollene om - studentens undervisning gjøres til gjenstand for refleksjon og diskusjon, og nye handlinger spilles ut. Samtalene, veiledningen og instruksjonen blir gjennomført i selve undervisningssituasjonen, eller i dens umiddelbare nærhet.

I denne artikkelen er konteksten knyttet til praksislærerens profesjonelle praksisveiledning i klasserom og verksted i en videregående skole. Som lærerutdanner har jeg i dag en profesjonell interesse i å studere den måten mesterlære vektlegger praksis og læring i praksisfellesskap på (hvor modell-læring inngår) inn i praksisopplæringen i lærerutdanningen. I artikkelen unders $\varnothing$ kes de mulighetene og utfordringene som kan knyttes til hovedtrekk i mesterlære og som nedfeller seg i praksislærernes eksamenstekster. Jeg bruker teori fra Kvale og Nielsen (1999), Lave og Wenger (1991, 2003, 2012) og Skagen (2013, 2016). Med bakgrunn i dette har jeg formulert følgende problemstilling: Hvordan bruker praksislarerne hovedtrekk fra mesterlare $i$ drøftinger av utfordringer og muligheter i praksisveiledning? 
Først presenterer jeg tidligere forskning og teori som er anvendt for å analysere og forstå studentenes eksamenstekster. Deretter følger en kort presentasjon av veilederstudiet og hvordan datamaterialet ble analysert og kategorisert. Etter en presentasjon av funnene i studien analyserer og diskuterer jeg til slutt hva studien kan bidra med av perspektiver inn i praksisveiledning i lærerutdanningen.

\section{Mesterlære - tidligere forskning i lærerutdanning}

Praksislæreren som modell, eller modell-læring, har de senere årene i liten grad vært diskutert som sentral strategi i praksisveiledning i lærerutdanning. Flere forskere har de siste årene reist diskusjon om og problematisert det dominerende kunnskapssynet som ligger til grunn for praksisopplæring i lærerutdanning i Norge (Skagen, 2016; Worum, 2016). Skagen (2016) hevder at handlings- og refleksjonsmodellen (HR-modellen), som ble utviklet av Handal og Lauvås (1983, 1999), har slått røtter de siste 30 årene som den viktigste modellen for veiledning i praksis i lærerutdanning. Han har foretatt en gjennomgang av fagfellevurderte artikler i norske og nordiske tidsskrifter, forskningsoversikter og monografier fra 1970-tallet og frem til 2000. Skagen (2016) oppsummerer med at:

[...] mesteparten av forskning og handlings- og refleksjonsstrategien har det til felles at den praktiske håndverksdimensjonen ikke blir forstått som en del av lærerstudenters og nyutdannede læreres profesjonalitet. [...] Lærerstudenters tilegnelse av metodekunnskaper skjer ikke bare ved refleksjon og verbalisering, men i en intuitiv og kontekstuell modus. Innvielsen i yrket skjer også ved imitasjon og intuitiv anvendelse av kunnskaper og ferdigheter som blir observert hos andre, eller som er erfart tidligere. (s. 76)

Skagen (2016) hevder at et kunnskapssyn i praksisopplæringen som er bygd på den praktiske håndverksdimensjonen, hvor læring og utvikling har sitt utgangspunkt i praksis og praksisfellesskap, og hvor modell-læring inngår, ikke blir forstått som grunnlag for lærerstudentens profesjonalitet. Kirsten S. Worum (2016) diskuterer det dominerende kunnskapssynet som ligger til grunn for praksisveiledning i lærerutdanningen. Basert på dokumentanalyse av hundre eksamensbesvarelser fra veilederutdanning for praksislærere fra perioden 20042014, konkluderer hun med at den dominerende ideen om kunnskap og læring i veiledning i lærerutdanning er knyttet til et individorientert kunnskapssyn i tråd med handlings- og refleksjonsmodellen. Dette bekreftes i flere andre studier (Søndenå, 2009; Bjerkholt, 2012). Ifølge Skagen (2013) er handlings- og refleksjonsmodellen utviklet på begynnelsen av 1980-tallet, særlig inspirert av datidens internasjonale forskning og teori om undervisning. Ikke minst har Carl Rogers' ideer om klientsentrert terapi fått en parallell i tanken om individ- og studentsentrert veiledning, slik man kan se i handlings- og refleksjonsmodellen (s. 33). Levende mesterlæretradisjoner som modell-læring og læring i praksisfellesskap, både innenfor håndverksfag og innenfor profesjonsutdanning, kunst 
og forskning, fikk ingen plass i handlings- og refleksjonsmodellen ifølge Skagen (2016, s. 74).

\section{Mesterlære}

Mesterlære har utviklet seg til en praksis som kan betraktes ut fra individuelle, relasjonelle og sosiale perspektiver på læring. Det er mulig å betrakte praksisen innenfor formell undervisning, samtidig som den også er en form for læring som oppstår utenfor formell undervisning, gjerne i verksted eller i andre autentiske læringslandskap.

Betegnelsen mesterlare brukes i dag på mange forskjellige måter, og er ikke entydig definert. I én forståelse av begrepet beskrives de lovfestede institusjonelle strukturer $i$ håndverksopplaeringen, som for eksempel lærlingeordningen i Norge med formelle kontrakter mellom lærling og lærested som avsluttes med fag- eller svennebrev (Andersen, 2003). I en annen forståelse benyttes mesterlære som en generell metafor - en prosess hvor en novise, en nybegynner, lærer av en mer erfaren person, en ekspert eller mester, på et område (Dreyfus \& Dreyfus, 1999, 2012). Lave og Wenger (1991) videreutviklet den tradisjonelle forståelsen av mesterlære fra å omhandle en relasjon mellom mester og lærling til å omfatte en relasjon mellom skiftende deltakelse og identitetsforankring i et praksisfellesskap. Slik Lave og Wenger (2003) ser det, kan individet ha flere roller samtidig, overfor mester og overfor andre individer i miljøet. Ut fra dette hevder forfatterne at læring er å være en del av fellesskapet, og ikke å lære om fellesskapet. Læring må derfor ses på som kontekstavhengig og kan ikke reduseres til teknikk og metode. Lave og Wenger forstår læring som «et integrert og uadskilleligt aspekt af social praksis» (2003, s. 33). Videre beskriver de læring som situert i praksisfellesskaper, og de har en oppfatning av læring som en del av den lærendes identitetsutvikling. Et situert perspektiv ser på kunnskapen som desentrert. Ordet situert refererer til en persons lokalisering et bestemt sted i den samfunnsmessige praksisen. Kunnskapen ligger i kulturen og i fellesskapet (Nielsen \& Kvale, 1999b, s. 244). Nielsen og Kvale (1999b) beskriver læringsbegrepet i mesterlære på denne måten: «Læring gjennom deltakelse $\mathrm{i}$ et praksisfellesskap med gjensidige forpliktelser for mester og lærling i en spesifikk sosial struktur over et lengre tidsrom» (s. 243). Kunnskapsutviklingen er slik det defineres ovenfor, den omfatter både sosialt distribuert og individuelt og personorientert tilpasset læringsarbeid. Lærling og praksisstudent eller mester og praksislærer brukes som synonyme begreper. Mesteren i min studie er en person som mestrer sitt fag, faglærer og praksislærer: han eller hun representerer fagets tradisjon og legemliggjør fagets autoritative kunnskap og verdier (Nielsen \& Kvale, 1999b, s. 243). 


\section{Modell-læring}

Et av flere hovedtrekk ved mesterlære er modell-læring. Modell-læring blir ofte omtalt som «læring ved observasjon av andres atferd og atferdens konsekvenser for dem» (Nielsen \& Kvale, 1999b, s. 243). Mange forskere er opptatt av modelllæring (modeling), uten at de definerer seg innenfor mesterlære. En av disse forskerne er Bandura (2001), hvor modell-læring er et nøkkelbegrep i hans sosialkognitive læringsteori og omfatter både imitative og identifikatoriske læreprosesser. Spesielt har Bandura fremhevet viktigheten av rollemodeller for hvordan individer tenker, føler og handler. Skagen (2013) stiller seg kritisk til en utvikling som viser en akademisering av veilederrollen i lærerutdanningen. «Veilederen fremstår ikke som modell som tilbyr eksempler på erfaren praksis til nybegynnere i læreryrket» (s. 127). Han hevder at veilederen har valgt å innta kommentatorrollen, og at lærerstudenten i stor grad er overlatt til seg selv i undervisnings- og læringsarbeidet. Praksislærerens kommentarer er først og fremst basert på studentens undervisning, ikke sin egen undervisning, som studenten knapt har sett (Skagen, 2013).

Lejonberg og Føinum (2018) bruker begrepene modellering og demonstrasjon om praksislærerens praksis. I en utdannings- eller opplæringskontekst har begrepene det til felles at de handler om et asymmetrisk forhold mellom to personer, der den ene - lærer eller praksislærer - behersker et fag eller en profesjon, mens den andre ikke gjør det på det gitte tidspunktet (Kvale \& Nielsen, 1999). En distinksjon i forståelsen av modell-læring kan være at i én tolkning av mesterlære skjer modell-læring i et praksisfellesskap, som sosial praksis, og inngår ikke som en del av en formell undervisning. En annen tolkning finner vi derimot hos Dreyfus og Dreyfus (1999) som har utviklet ferdighetsmodeller uten å ta hensyn til den sosiale konteksten. Dreyfus og Dreyfus er opptatt av at læring og utvikling skjer også der den lærende bare forholder seg til én person.

\section{Læring i praksisfellesskap}

Det som kjennetegner begrepsdannelsen omkring ideen om mesterlære i dag, er vektleggingen av at læring er noe som skjer når man tar del i praksis - ikke $\mathrm{i}$ undervisning. Læring finner ideelt sted gjennom legitim, perifer deltakelse i et praksisfellesskap, der de tre betegnelsene må sees i sammenheng (Lave \& Wenger, 1991, s. 35). Med legitim deltakelse forstår jeg at den lærende (lærerstudenten) er tatt opp som medlem i fellesskapet (praksisskolen). Perifer deltakelse er det motsatte av full deltakelse. Den ferske lærerstudenten (nybegynneren) vil naturlig nok befinne seg $\mathrm{i}$ ytterkanten av aktivitetene $\mathrm{i}$ praksisfeltet når hun starter praksis. Legitim, perifer deltakelse gjelder da prosessen som fører til at den nyankomne (praksisstudenten) blir en fullverdig del av praksisfellesskapet. Innlæringen av fagets eller profesjonens mange ferdigheter, hvor språk inngår som et vesentlig element, er trinn på veien mot å beherske faget eller profesjonen. Gjennom å jobbe med faget og profesjonen, få mulighet over tid i fellesskapet til å praktisere og bygge på med nye oppgaver i takt med det den lærende mestrer, 
vil den lærende oppleve en fag-/profesjonsidentitet gjennom mestringsprosessen. Nielsen (1999) lanserte begrepet deltakerbaner, «at mesterlære er å oppfatte som en prosess der lærlingene hele tiden lærer av så vel andre lærlinger som viderekomne og mestere som er til stede i praksisfelleskapet» (s. 112). I dagens praksisrom i lærerutdanning er de relasjonelle rammene ofte en-til-en, én praksislærer og én student sammen over tid. Hovedtrekk ved den rådende handlings- og refleksjonsmodellen består av en førveiledning, en samtale om det som skal foregår i studentens undervisning. Deretter observerer praksislæreren studentens praksis. Denne praksisen avsluttes med samtale - en etterveiledning - omkring studentens erfaringer fra undervisnings $\varnothing \mathrm{kta}$. Det er studentens praksis som er i fokus. Studentene har ifølge Skagen (2013) i liten grad adgang til praksisfellesskapet på praksisskolene gjennom dagens organisering av praksisopplæringen.

\section{Relasjoner i praksisfellesskapet}

Tradisjonelt sett foregikk store deler av mesterlære i samspillet mellom mester og svenn/lærling. Historisk var denne relasjonen preget av asymmetri, en språklig eller nærmest taus kunnskapstradisjon der observasjon eller instruksjon var dominerende (Andersen, 2003). I dag har dette endret seg, det er mer fokus på et likeverdig samspill med ulike roller. I tillegg ser vi i mindre grad en-til-en-forhold og desto mer at læring foregår i et praksisfellesskap bestående av relasjonene mellom flere fagpersoner (Kvale \& Nielsen, 1999). Relasjonskompetanse er et vidt begrep og kan defineres som «ferdigheter, evner, kunnskaper og holdninger som etablerer, utvikler, reparerer og vedlikeholder relasjoner mellom mennesker» (Spurkeland, 2014, s. 17). Forfatteren snakker her om respekt-, kjærlighets-, vennskaps- og vennlighetsrelasjoner som et menneske omgir seg med i møte med ukjente mennesker. I praksisopplæring i lærerutdanningen vil dette handle om hvordan de sosiokulturelle forholdene rundt den lærende planlegges og tilrettelegges. Hvordan møter praksisskolen de nye studentene, hvordan etableres de inn i fagfellesskapet for å skape faglig og sosial trygghet rundt studentene? Hvordan skal de veiledes, og av hvem? Dette er viktige spørsmål for studentens faglige utvikling og profesjonalisering.

\section{Kritikk av mesterlære}

\section{Imitasjon}

Mesterlære er blitt kritisert for å fremme et reproduktivt syn på læring uten selvstendig kritisk refleksjon og for å innebære imitasjon eller kopiering. De senere årene har det gjennom ulik forskning kommet frem eksempler som viser et annet bilde. Ejgil Jespersen (1999) peker på at mesterlære ikke bare er imitasjon av mesteren, men også kreativ skaping av egen stil gjennom møter med flere mestere eller praksismiljøer. Nilssen (2018) viser til Vygotskij (1987) som hevder 
at for å forstå læring i den nærmeste utviklingssonen, er det nødvendig med en reevaluering av begrepet imitasjon. Imitasjon i Vygotskijs forståelse er bare mulig i den form og utstrekning der det også ligger en forståelse, en mental handling, til grunn. En person kan bare imitere det som ligger innenfor dennes eget mentale potensial, det som ligger innenfor den nærmeste utviklingssonen (Nilssen, 2018, s. 117). Schön (1988) avviser at mesterlære kan forstås som at man kopierer andres handlinger. Det er heller slik at novisen eller lærerstudenten ofte bruker disse erfaringene til å utvikle sin egen arbeidsstil. Schön (1988) bruker begrepene «refleksiv imitasjon», «imitativ rekonstruksjon» og «selektiv rekonstruksjon» til å beskrive slike prosesser. Ideen er at eleven eller praksisstudenten må inngå i et avhengighetsforhold for senere å kunne bli uavhengig.

\section{Refleksjon}

Refleksjon er et vidt begrep som har fått en stor plass i de fleste profesjonsutdanninger. At lærerstudentene våre skal utvikle kompetanse i kritisk refleksjon, er i dag en selvfølge. Lærerstudentens kompetanse i å begrunne og analysere egen praksis vil i mesterlære være uløselig knyttet til praktisk lærerdyktighet som to ikke adskilte kompetanser. Øvelser, utprøving, direkte handling og praktisk deltakelse, kombinert med språk og fortellinger, er helt avgjørende (Lave \& Wenger, 2003). En annen oppfatning understreker det tause aspektet ved mesterlære. Ord og språk blir nedprioritert eller til og med overflødige i forhold til demonstrasjon og observasjon, fordi kunnskapen kommer til uttrykk i handlingene, ikke i forklaringene eller begrunnelsene for disse, men $i$ selve handlingen (Nielsen \& Kvale, 1999a).

\section{Metode}

Artikkelens utgangspunkt er 10 av 31 gruppebaserte eksamensbesvarelser fra en pilot (7,5 studiepoeng) som lærere gjennomførte ved en av NTNUs universitetsskoler i vårsemesteret 2016. Dette er en kombinert videregående skole. Denne artikkelen er en delstudie i forskningsprosjektet Fra praksis tilbake til praksis (se Engvik \& Østern, 2017). Hensikten med denne artikkelen er å utvikle mer kunnskap om og innsikt i hvordan hovedtrekk fra mesterlære anvendes i praksisopplæring i lærerutdanning.

Målet med emne 1 (7,5 studiepoeng) i videreutdanningsstudiet var at praksislæreren skulle utvikle profesjonsidentitet som praksislærer innenfor sitt fagområde. Det var også et mål at studiet skulle bidra til skoleutvikling, og at praksisopplæringen skulle utvikles til en integrert del av skolens faglige utviklingsarbeid. Utdanningen skulle gi $\varnothing \mathrm{kt}$ forståelse for profesjonsutvikling av praksislærere og hvordan utvidet kompetanse som praksislærer kan bidra til å utvikle lærerstudentens kompetanse i et praksisfellesskap. Videreutdanningen var skolebasert, og all undervisning og alle læringsaktiviteter foregikk ved skolen. Studiet pågikk 
over et semester, og lærerne kunne bruke skolens fastlagte teamtid til å delta i utdanningen (se Engvik \& Østern, 2017).

Til eksamen skulle praksislærere i grupper på tre innen samme fagområde levere en fagtekst på inntil 2000 ord, hvor utviklingen av profesjonskompetanse som praksislærer skulle settes inn i en faglig kontekst. I denne teksten drøfter praksislærerne muligheter og utfordringer fra egen arbeidsplass belyst gjennom datamateriale fra denne og gjennom teori om praksisopplæring. De skulle vise at de var i stand til å anvende kunnskap inn i en problemstilling fra egen skole og med relevans for praksisopplæring på fagområdet. I instruksjonen til eksamensoppgaven ble kursdeltakerne oppfordret til å utforme en casebeskrivelse med utgangspunkt $i$ dilemma-situasjoner og utfordringer de mфtte som praksislarere ved egen skole, og drøfte hvordan de ville reflektere over dette i praksisveiledningen.

\section{Tematisk analyse}

Basert på innholdet $i$ studieplanen ble det i første fase gjennomført en tematisk analyse av samtlige eksamenstekster med utgangspunkt i seks tema. Kvalitativ tekstanalyse handler om å lese og analysere håndskrevne tekster, trykte kilder og arkiverte dokumenter av ulike slag (Widén, 2017). Johannessen, Tufte og Christoffersen (2016) skiller ikke mellom tekstanalyse og analyse av annen type kvalitative data i tekstform. Hensikten er i begge tilfellene å få frem meningsinnholdet i teksten (Johannessen et al., 2016). Innholdet i studieplanen omhandlet tema som kommunikasjon, mangler kompetanse, etikk, veiledertiltak, system og selvrefleksivitet. I den videre analysen under emnet system, som omhandler teorigrunnlag i studentoppgavene, støttet studentene seg til noen sentrale teorier, som teorien om praksisarkitekturer (Kemmis, Wilkinson, Edwards-Groves, Hardy, Grootenboer \& Bristol, 2014) og teori om mesterlare (Nielsen \& Kvale, 1999a). Teorien om praksisarkitekturer utgjorde det teoretiske grunnlaget i veiledningsstudiet. Teori om mesterlære ble presentert i én forelesing på kurset, presentert som erfaringer fra den yrkesfaglige læringstradisjonen i veiledning og instruksjon fra den treårige yrkesfaglærerutdanningen ved NTNU. Det er de ti eksamensbesvarelsene som støtter seg til teori om mesterlare, som denne delstudien omhandler (Engvik \& Østern, 2017).

$\AA ̊$ analysere og tolke andres utsagn og meninger betinger at en er oppmerksom på de etiske sidene ved dette. Det er en risikofaktor at det tillegges andre meninger enn deltakerne kan kjenne seg igjen i. I analysen av tekstene valgte jeg tematisk de fire definisjonene på mesterlære som tolkningsramme: laering $i$ praksisfellesskap, laering som faglig identitetsutvikling, laring uten formell undervisning, laring gjennom handling - evaluering gjennom praksis. Kvale og Brinkmann (2017) beskriver tematisk analyse og tolkning av kvalitative data som en analyse med bruk av tre tolkningsnivåer. Først kan man velge å bearbeide dataene i forhold til deltakernes selvforståelse og referere i forhold til dette. Meningsinnholdet i teksten er en omskrevet fortetting av deltakernes egne synspunkter, 
slik forskeren forstår dem. Det er aktuelt å bruke direkte sitater fra deltakernes skriftlige fremstillinger i eksamensbesvarelsene. Dette omtaler Kvale og Brinkmann (2017) som tekstncert nivå. Neste nivå er å tolke dataene gjennom identifisering av temaer og mønstre. Her kan forskeren tillate seg å stille seg kritisk til teksten, en tillater seg å lese mellom linjene, men holder seg innenfor konteksten av det som er en allment fornuftig tolkning. Det tredje nivået innebærer tolkning og drøfting opp mot relevant teori. Her benyttes en teoretisk ramme ved tolkningen av eksamenstekstene som mest sannsynlig går lenger enn til deltakernes selvforståelse, og også lenger enn en tolkning basert på sunn fornuft. I artikkelen tolkes funnene i lys av ulike forståelser av rådende veiledningsmetoder i praksis i lærerutdanning og med hovedtrekk fra mesterlære i praksisveiledning i fokus.

\section{Koding og kategorisering}

Koding anses å være den sentrale koblingen mellom å samle data og utvikle en gryende teori som forklarer disse dataene (Charmaz, 2006). Kodingen innebar at det ble skrevet ned ord i tilknytning til gjennomlesingen som best definerte den opplevelsen som blir beskrevet av informanten. Eksempler på kodeord var «viser frem», «hindringer», «klør i fingran», «usynlig lærer og praksislærer». Gjennom prosessen utviklet jeg en tabell med ytringene i én kolonne og kodeordene i en annen. Det videre analysearbeidet innebar å stadig sammenholde empiri og teoretiske begreper (Charmaz, 2006). Dette innebar å tolke materialet i lys av teoretiske begreper eller hovedtrekk knyttet til mesterlære for å utvikle strukturene i materialet. Materialet ble utviklet fra å være overveiende deskriptivt til et mer teoretisk nivå (Kvale \& Brinkmann, 2017). Praksislærernes tekster som var knyttet til aktuelle veiledningssituasjoner mellom lærerstudent og praksislærer, ble gjennom analysen utviklet til grunnleggende ny kunnskap. Dette siste trinnet i analyseprosessen førte til at jeg kunne sammenfatte tekstene til kategorier. Kategorisering innebærer at informasjon om det samme temaet samles i én kategori (Charmaz, 2006). De tre hovedkategoriene som utviklet seg, er: Modell-laring, Relasjonskompetanse og Praksisfellesskap.

\section{Forskningsetikk}

Prosjektet ble godkjent av NSD med prosjektnummer 48370 i mai 2016 med tittel: Utvikling av kompetanse og forståelse i et skolebasert videreutdanningstilbud for praksisveileder. Et forskningsetisk dilemma som bør nevnes, er min posisjon i forskningsprosjektet. Jeg har deltatt i utvikling av studieplanen, har undervist på studiet, og sammen med to kolleger har jeg veiledet og sensurert eksamenstekstene. Ut fra dette kan min rolle i forskningsprosjektet ikke betraktes som «nøytral». Nærheten til en videreutdanning jeg var involvert i og til eksamenstekster jeg har veiledet og sensurert, er et forskningsetisk dilemma jeg er bevisst (Jacobsen, 2011). 


\section{Studiens funn}

I denne studien rettes oppmerksomheten mot praksislærernes beskrivelse av tema og mønster i deres profesjonskunnskap reflektert inn i eksamensoppgavene, hvor teori, ideer og hovedtrekk fra mesterlære anvendes som teori eller tilnærming i drøfting av casene. Gruppene (Gr.) er sortert fra 1 til 10 og det henvises til disse bak direkte sitater. I problemstillingen stiller jeg spørsmålet: Hvordan bruker praksislarerne hovedtrekk fra mesterlare $i$ drøftinger av utfordringer og muligheter i praksisveiledning? I fortsettelsen blir utfordringer og muligheter i praksisveiledning fremstilt og diskutert under ett. I analysen av eksamenstekstene utviklet det seg tre hovedtemaer/kategorier:1) Modell-læring, 2) Relasjonskompetanse, og 3) Praksisfellesskap.

\section{Modell-læring - utfordringer og muligheter}

I casene inngår modellbasert veiledning eller modellering som synonyme begreper til modell-læreren. Mulighetene, eller hvordan dette kan gjøres i praktisk veiledning, reflekteres inn på forskjellige måter i casene. I noen caser fremheves betydningen av at lærerstudentene observerer det praksislærer omtaler som «kroppslig undervisning». Basert på tidligere erfaringer har praksislærerne observert den uerfarne praksisstudenten som «sliter» med at elevene tar over kontrollen i klasserommet. I en case drøftes hvordan lærerstudenten kan observere veilederens undervisning og gjennom dette «oppdage at autoritet er noe man tar og ikke noe man får» (Gr. 4). Studenten kan:

[...] se hvordan veilederen bruker kroppen til å forsterke verbale beskjeder til klassen. Veileder vil trolig bevege seg rundt i rommet, feste blikket på urolige elever, og prøve å trekke slike elever inn i en felles dialog med klassen ved å henvende seg til dem ved å bruke navnet på eleven og stille direkte spørsmål. Et åpent og hyggelig kroppsspråk kan likevel i en slik situasjon være en mild korreks som fungerer uten at noen elever føler seg støtt. (Gr. 4)

I denne casen fremheves det et ønske om «å vise studenten hvordan hun kroppslig beveger seg og agerer i rommet for å ivareta en tydelig, men myk og smidig ledelse i klasserommet» (Gr. 4). I casen kommer det frem at i observasjon, som knyttes til praksisveiledning i slike situasjoner, er hensikten «at studenten lærer at det er greit å gi fra seg kontrollen, men at det er hun som skal styre når det skal skje» (Gr. 4).

I en annen case knyttes hovedtrekk fra mesterlæren til det kinetiske:

Det kinetiske menneske lærer ofte best ved å ta på [...] vår erfaring med denne type læring er at elever som observerer og hermer eller kopierer andres arbeid, på sikt vil måtte reflektere og ta bestemte valg i videre arbeid. Vi tenker at det er her kreativitet og utvikling skjer. (Gr. 5) 
I en case blir problemet med at elevene ofte mottar lite veiledning under forberedelsene til muntlige vurderingssituasjoner, og mulige konsekvenser for praksisopplæring, tatt opp:

[...] faglærernes veiledning må være spesifikk, kriteriebestemt og konkret for at de muntlige ferdighetene skal kunne bli identifisert og tatt på alvor; da må også veiledningen av studentene bære preg av at de observerer en vurderingskultur hvor slike tilbakemeldinger blir gitt. I dette perspektivet er det nærliggende å trekke inn et begrep som modellering. Siden muntlighet i den norske skolens vurderingskultur står relativt svakt, bør studentene bli vist hvilke grep du kan gjøre for å ivareta muntlighet innenfor ferdighetsperspektivet. Modellering kan derfor være et nyttig prinsipp i de tilfellene studentene har få knagger fra før av til å henge praksisen på. (Gr. 1)

I denne casen trekkes begrepet modellering inn som et spesifikt, kriteriebestemt og konkret eksempel på hvordan praksislærer og faglærer viser praksisstudenten hvilke grep som kan gjøres i en muntlig vurderingssituasjon. En gruppe språklærere er opptatt av det samme. De begrunner valg av modell-læring i undervisning og praksisopplæring og kobler dette til «hvordan de selv bruker modelltekster i skriveopplæringa» (Gr. 5). De har gjennom dette studiet blitt nysgjerrige på metoden og ønsker å utforske dette nærmere. I en case beskrives observasjon av praksislæreren på denne måten: «når praksisstudenten veksler mellom å undervise selv og å observere sin praksislærer, kan hun selv se hva han eller hun gjør» (Gr. 2). I casen fremheves det at «ved å la studenten observere mer, kan man bruke det pedagogiske virkemidlet 'å vise' og gjennom diskusjoner i forkant og etterkant kan studenten oppnå ny innsikt i læreryrket» (Gr. 2). I fire caser hevdes det at kjernen i lærerarbeid er undervisning, derfor kan observasjon og modellering være viktigere enn selve refleksjonssamtalene.

I flere caser fremheves det at i dagens praksisopplæring i lærerutdanningen er hovedproblemet og en viktig utfordring at mesteren er «usynlig», at «praksislæreren har hatt en tendens til å innta en tilbakelent rolle inn mot studenten», og at de som praksislærere «ofte har sittet og klødd i fingrene etter å gripe inn og foreslå andre måter å gjøre ting på i timene» (Gr. 4, 5, 7 og 8). Det fremheves at «tid til observasjon av den erfarne praksislæreren kan være med på å skape tryggheten som noen lærerstudenter kan savne» (Gr. 4). «Vi synes veilederen i altfor stor grad bare observerer og får dermed ikke vist frem og delt sine kunnskaper og erfaringer som ønsket» (Gr. 5). Flere grupper drøfter det en gruppe beskriver som det har «klфdd i fingran» eller ønsket om «å vise studenten hvordan ulike didaktiske løsninger kan være til hjelp når studenten knoter» $\mathrm{i}$ praktisk undervisning (Gr. 5, 7 og 8).

Ingen av casene konkluderer med enten-eller, men at både observasjon av praksislærerens undervisning og refleksjonssamtale vil være viktige bestanddeler i studentens profesjonelle utvikling. 


\section{Relasjonskompetanse - utfordringer og muligheter}

I drøftingene i casene fremheves de ulike mulighetene for at modell-læring kan fungere. Det viktigste er at man «har utviklet et respektfullt forhold til studenten i forkant» og videre at «det er en forutsetning at praksisveileder faktisk selv gjør en god jobb i klasserommet» (Gr. 1). I tillegg vil observasjonen kunne bidra til å korrigere studentens opplevelse ved at praksislæreren viser henne hvordan hun styrer en klasse på en mild måte, og hvordan hun tar tak i en urolig situasjon $\mathrm{i}$ klasserommet. Denne observasjonen kan bidra til at studenten ikke tror «at bare hun har urolige elever, siden hun er fersk» (Gr. 4). «Dette kan trygge studenten før hun skal ut i yrket og er viktig for å unngå å skremme studenten vekk fra læreryrket» (Gr. 4).

Av utfordringer beskriver deltakerne hvordan de kan løse det de omtaler som motsetningen mellom mesterlære og handlings-/refleksjonsmodellen. I en case ser de for seg at dialogen mellom student og praksislærer kan skje i klasserommet, i selve konteksten, med elevene til stede. «En måte å gjøre dette på, er å la mesteren for eksempel starte undervisningsøkta med å vise en god oppstart av en time, for så å la studenten prøve det samme, altså at mesteren veileder studenten underveis i undervisningsøkta» (Gr. 2). «Dersom man har blitt enig om denne metoden på forhånd, og elevene er informert om det, vil også elevene bli mer bevisst på læringsprosesser» (Gr. 2). I Gruppe 6 problematiseres det deltakerne ser som et mulig motsetningsforhold mellom veiledning gjennom refleksjon med bruk av responssløyfer og å gi råd til studenten. Det fremheves at «det kan være best å bruke observasjon i starten av veiledningsperioden slik at studenten får et trygt fundament. Studenten kan bli veiledet mer gjennom egen refleksjon senere i studiet» (Gr. 6). Her drøftes observasjon av praksislærer/mester i arbeid og refleksjon og samtale som to motsetninger, avhengig av studentens progresjon og kompetansenivå. Flere grupper peker på sentrale forutsetninger for at modelllæring kan anvendes som tilnærming i veiledning. «Det viktigste er at veileder og student har samme faglige eller profesjonsbakgrunn»(Gr. 1 og 2), «og at praksislærer faktisk selv gjør en god jobb i klasserommet»(Gr. 1, 2, 7 og 8). I omtrent halvparten av casene drøftes betydningen av at praksislæreren ikke bare har innsikt og kan faget sitt, men også «innehar relasjonskompetanse eller kommunikativ kompetanse» (Gr. 1, 4, 7 og 8).

\section{Praksisfellesskap - utfordringer og muligheter}

I flere caser fremheves $\emptyset$ nsket om at man beveger seg mot det flere omtaler som «en moderne form for mesterlære»(Gr. 1 og 6), som ikke vektlegger den ene mesteren, «men som lar studenten være en del av et fellesskap med flere mestere som veiledere» (Gr. 1, 6, 7 og 8). Mulighetene som beskrives og drøftes, handler om at ved «å gi studentene muligheten til å observere flere faglærere/mestere i praksis, se hvordan ulike mestere løser oppgaver» (Gr. 1 og 7), vil den lærende få tilgang til flere måter å løse didaktiske utfordringer og oppgaver på. Utsagn som «at studenten bør få observere flere mestere innenfor samme fag i løpet av 
praksisperioden», går igjen i flere caser (Gr. 1, 7 og 8). I en case drøfter de betydningen av «at praksisstudenten forholder seg til minst to faglærere, og veksler mellom å observere og undervise i klassene» (Gr. 8). I en annen case pekes det på muligheten for «at tilstedeværelse og observasjon av enkelte situasjoner kan være et viktig supplement til den sterke språklige/dialogiske virksomheten som fremheves innenfor konstruktivismen» (Gr.7).

Utfordringer med å organisere for en praksisopplæring i praksisfellesskap drøftes i flere caser. Utsagn som at «et praksisfelleskap rundt studenten ikke naturlig er tilpasset eller organisert inn som rammevilkår i dagens praksis i lærerutdanning», går igjen i flere caser (Gr. 1, 4, 7, 9 og 10). Gruppene drøfter på ulike måter at hovedtrekk fra mesterlære «ikke er egnet for veiledning sånn som praksisperiodene er lagt opp i dag, verken praktisk eller pedagogisk», og at «det vil kreve en annen organisering av praksis», uten at det konkretiseres nærmere hvordan dette kan organiseres (Gr. 1, 4 og 7).

\section{Diskusjon}

I analysen knyttes funnene opp mot teori for å forstå og videre drøfte hva disse innebærer. Jeg går først inn på praksislærernes ønske om å vise frem sin kompetanse for praksisstudentene i praktisk undervisning, deres ønske om å være modell-lærere i ulike kontekstuelle læringssituasjoner. Deretter rettes oppmerksomheten mot betydningen av gode og trygge relasjoner mellom praksislærer og student, en vesentlig forutsetning i alt læringsarbeid, også mesterlære. Tilslutt drøftes om - eller hvordan - læringsfellesskap rundt studentens praksis kan utvikles i dagens lærerutdanning.

\section{Hvorfor modell-læring - utfordringer og muligheter?}

Et sentralt funn i denne studien omhandler det praksislærerne opplever som utfordringer med den «usynlige» mesteren: praksislæreren som påtar seg en selvpålagt tilbakelent rolle, samtidig som det «klør i fingran» etter å hjelpe studentnovisen med praktiske råd i for eksempel oppstart av en time, når studenten «knoter», eller vise hvordan ulike kroppslige didaktiske ageringer kan bidra til trygghet og ro i elevgruppen, eller hvordan studentene kan bli vist hvilke grep man kan gjøre for å ivareta muntlige vurderingssituasjoner. Slike utsagn kan tyde på at praksislærerens profesjonelle praksis er tolket inn i én bestemt didaktisk ramme rundt praksis, hvor modell-læring ikke inngår. Selv om flere forskere de senere årene har tatt til orde for en utvikling der praksislærere også er modelllærere, kan det se ut som om at dette ikke er internalisert i praksislærerens profesjonelle rolleforståelse (Skagen, 2013, 2016; Lejonberg \& Føinum, 2018). Praksislærerne ser muligheter, og de ønsker i større grad å invitere til observasjon og demonstrasjon av egen praksis, både når studenten opplever utfordringer $\mathrm{i}$ undervisningen og når praksislæreren har erfaring med at dette kan bidra til 
studentens læring og læreprosess, innenfor studentens utviklingssone. Praksislærerne $\emptyset$ nsker å forberede praksisstudenten på hvor oppmerksomheten bør rettes og samtale om dette både i forkant og etterkant av observasjonen. Gjennom en slik tilnærming kan man $\varnothing$ ke bevisstheten om læring og undervisning (Lejonberg \& Føinum, 2018; Nielsen \& Kvale, 1999a). Praksislærerens praktiske kunnskap er innebakt $\mathrm{i}$ hennes undervisning gjennom flere års erfaring, den er personlig og må kanskje vises i praksis for å kunne formidles videre til studenten.

I praksislærernes drøftinger kommer det frem at de bør utnytte sin egen dyktighet til å undervise og veilede lærerstudenter i større grad enn de gjør i dag. I en gruppe drøftes imitasjon eller «hermer eller kopierer andres arbeid» (Gr. 5), og gruppen henviser til (Skagen, 2000, 115) at «det gode eksemplet er ikke preget av ensidig moralisme der den rette vei blir pekt ut, men er åpen for fortolkning. Det er flersidigheten og ubestemtheten ved eksemplet som gir studenten frihet til å bestemme selv, men bestemmelsen er definitivt inspirert av det gode eksemplet». I flere caser er de opptatt av det Dreyfus og Dreyfus beskriver som positiv utfordring ved at lærlingen observerer flere mestere: «Det å arbeide hos mange mestere destabiliserer og forvirrer lærlingen, slik at han ikke bare kan kopiere en enkelt mester. Dermed blir han tvunget til å skape sin egen, nye stil» (1999, s. 6566). Det pekes på at observasjon av mesteren i enkelte undervisningssituasjoner kan være et viktig supplement til den sterke språklige/dialogiske virksomheten i praksisveiledning, uten at dette utdypes nærmere. Resultater i denne studien kan tolkes dithen at praksislærerne i større grad enn tidligere $\emptyset$ nsker å anvende modelllæring eller modellering som en av flere tilnærminger i praksisveiledning. I modell-læring inngår både praktiske råd underveis, observasjon og demonstrasjon av egen undervisningspraksis, både verbalt og kroppslig.

\section{Hvorfor relasjonskompetanse - utfordringer og muligheter?}

I flere caser er praksislærerne opptatt av å koble modell-læring til refleksjon i læreprosessen. Det fremheves at en vesentlig forutsetning eller utfordring for at praksislæreren skal kunne være modell og inspirator for lærerstudenten gjennom «å vise hvordan», er at studenten får tilgang til praksislærerens hva, hvordan og hvorfor, til felles refleksjon omkring det observerte (Schön, 1988, 2012). Flere grupper peker på praksislærerens relasjonskompetanse som en sentral forutsetning for at modell-læring kan anvendes som tilnærming i veiledning: «Det viktigste er at veileder og student har samme faglig- eller profesjonsbakgrunn» og «at praksislærer faktisk selv gjør en god jobb i klasserommet». I halvparten av casene drøftes betydningen av at praksislæreren ikke bare har innsikt og kan faget sitt, men også «innehar relasjonskompetanse eller kommunikativ kompetanse». $\AA$ inneha relasjonskompetanse eller kommunikativ kompetanse forventes hos enhver praksislærer i dag, men kanskje er dette spesielt viktig i sammenheng med modell-læring gjennom for eksempel demonstrasjon og observasjon av praksislærerens undervisning? Som profesjonell praksislærer hvor modell-læring inngår, vil analyse av studentens nærmeste utviklingssone og hjelpebehov legges 
til grunn for hvilke veiledningsmetodiske tilnærminger som velges til enhver tid (Nilssen, 2018).

En mulighet som fremheves i drøftingene i casene er at når den gode og trygge relasjonen mellom praksislærer og student er på plass, kan for eksempel undervisning som to-lærere sammen i verksted på skolen være en god ramme og mulig inngang til modell-læring gjennom å vise hvordan, både kroppslig og via eksempler, eller at praksislæreren demonstrerer og instruerer i praksissituasjonen (Nielsen \& Kvale, 1999a). Veiledningssamtaler kan kobles direkte opp mot demonstrasjoner og praktiske undervisningssituasjoner i klasserom og verksted, og det er innforstått i mesterlæren «at ikke alt fullt ut kan forklares eller formidles verbalt» (Skagen, 2013, s. 125). Den profesjonelle veiledningssamtalen, praktisk og didaktisk ferdighetskunnskap, enten denne gjennomføres før, underveis eller etter undervisning, enten det er praksislærer eller student som underviser, handler om å verdsette andre som gode samtalepartnere. Dette underbygges som en grunnleggende viktig kompetanse i drøftingene i flere caser. Denne kompetansen handler om hvem som får snakke, empati, hvem det blir lyttet til, og hvordan likeverdighet blir tolket. Betydningen av kvalitet i praksislærerens evne til å lytte og observere og å veilede mot en profesjonell yrkesutfoldelse som er omgitt av tillit, er sentrale forhold i alle veiledningskontekster ifølge Engvik (2018). Slike ferdigheter bygger på erfaring, personlig identitet, etiske verdier og et kunnskapssyn som er internalisert i den enkelte i møte med ulike praksiser: profesjonell lærerpraksis og som profesjonell praksislærer i lærerutdanningen. Disse kompetansene er av allmenngyldig karakter som forventes hos enhver praksislærer, men kanskje er dette spesielt viktig sett i sammenheng med anvendelse av hovedtrekk fra mesterlære, som for eksempel demonstrasjon og observasjon av praksislærerens undervisning.

\section{Hvorfor praksisfellesskap - utfordringer og muligheter?}

Organiseringen av praksisopplæringen i lærerutdanningen i Norge er i dag i stor grad knyttet til relasjonen mellom én praksislærer og én student. Et sentralt funn i denne studien er at i et flertall av casene i studien ser praksislærerne muligheter $i$ at studenten er en del av et fellesskap med flere mestere som veiledere. Det drøftes i liten grad hva som forstås med et praksisfellesskap. I en case konkretiseres dette til minst to faglærere, der studenten veksler mellom å observere og undervise i klassene. I en annen case fremheves betydningen av å gi studentene muligheten til å observere flere faglærere/mestere i praksis, se hvordan ulike mestere løser oppgaver, at dette vil kunne gi den lærende tilgang til flere måter å løse didaktiske utfordringer og oppgaver på.

Med introduksjonen av situert læringsteori (Lave \& Wenger, 1991) skjedde det en videreutvikling og dreining i mesterlære, fra fokus på indre mentale aspekter i læring til å ha et fokus på læringsmiljøer og adgang til læring, adgang til konkrete, levende rom hvor selve læringen finner sted og ulike landskap og personlige deltakerbaner på tvers (Tangaard \& Nielsen, 2006). I et sosialt 
perspektiv på læring ligger mye av fagkunnskapen i relasjonene mellom fagpersoner. Det fremheves i flere caser at dagens organisering av praksis er en utfordring, eller et hinder, for praksisstudentens posisjonering og adgang til et praksisfellesskap bestående av flere enn praksislæreren. Praksisfellesskapet er sammensatt og komplekst. Praksis i lærerutdanningen kan handle om studentens adgang til et fellesskap i praksisskolen som innbefatter flere praksislærere, faglærere, andre praksisstudenter, nyutdannede lærere, eller studentnoviser i sitt første studieårs praksis og mer erfarne studenter sammen (Elmholdt, 2003; Lave $\&$ Wenger, 1991, 2003, 2012). Rammene rundt praksisperiodene er i dag til hinder for studentenes langvarige innvielse og deltakelse i et praksis- og læringsfellesskap i praksisskolen. Et første steg på veien kan være det praksislærerne diskuterer som en mulighet: gi studentene adgang til å observere flere faglærere i praksis, se hvordan ulike mestere løser didaktiske oppgaver.

\section{Avsluttende kommentar}

I denne artikkelen har jeg presentert en studie av hvordan praksislaererne bruker hovedtrekk fra mesterlare $i$ drøftinger av utfordringer og muligheter i praksisveiledning. Basert på resultatene $\mathrm{i}$ denne studien er det noen hovedtrekk fra mesterlære som trer frem som interessante perspektiver i videreutvikling av praksisopplæring i lærerutdanningen. Et sentralt funn i studien omhandler det praksislærerne opplever som utfordringer med den «usynlige» mesteren. De $\emptyset$ nsker i større grad å være modell-lærere, vise sin kunnskap til praksisstudenten, både kroppslig og gjennom annen form for kommunikasjon. Den praktiske håndverksdimensjonen, hvor læring og utvikling har sitt utgangspunkt $\mathrm{i}$ praksisfellesskap, hvor modell-læring inngår, kommer frem som en ønsket utvikling hos praksislærere som en av flere tilnærminger i utvikling av lærerstudentenes profesjonalitet. I denne studien gir praksislærerne til kjenne, på ulike måter, et $\emptyset$ nske om at andre ressurser kan bringe inn nye perspektiver, det være seg andre praksislærere, faglærere, medstudenter eller andre i skoleorganisasjonen (Lave \& Wenger, 2003, 2012; Nielsen, 1999; Nielsen \& Kvale, 1999a; Nilssen, 2018). Selv om mesterlære er gammel, viser praksislærernes refleksjoner over muligheter og utfordringer i praksisopplæringen et nyansert bilde av hovedtrekk fra mesterlære i bruk i praksisveiledning.

Dette er en liten studie basert på analyse av ti gruppebaserte eksamenstekster fra ett videreutdanningsstudium for lærere og praksislærere ved én videregående skole. Tidligere forskning og resultater fra denne studien kan tyde på et behov for videreutvikling av praksis i lærerutdanning. Å gi praksisstudentene adgang til praksisfellesskapet i praksisskolene kan være et vesentlig bidrag til utvikling av studentenes profesjonsidentitet og profesjonskompetanse i lærerutdanningen. 


\section{Om forfatteren}

Kari Henriette Hansen er førstelektor ved Norges teknisk-naturvitenskapelige universitet (NTNU). Hennes forskningsinteresser er knyttet til yrkesopplæring med fokus på interesse-/yrkesdifferensiering, tidlig fordypning i $\mathrm{Vg} 1$, samt likestilling, makt og demokrati.

Institusjonstilknytning: Institutt for lærerutdanning, NTNU, 7491 Trondheim. E-post: kari.hansen@ntnu.no

\section{Referanser}

Andersen, K. (2003). Innføring i mesterloere, yrkesdidaktikk og veiledning. Kristiansand: HøyskoleForlaget.

Bandura, A. (2001). Social cognitive theory: An Agentic Perspective. Annual Review of Psychology, 52, 1-26.

Bjerkholt, E. (2012). Apning av lukkede rom. Doktorgradsavhandling, Universitetet i Oslo.

Charmaz, K. (2006). Constructing Grounded Theory: a practical guide through qualitative analysis. London: Sage.

Dreyfus, H. \& Dreyfus, S. (1999). Mesterlære og ekspertenes læring. I K. Nielsen \& S. Kvale (red.), Mesterloere, lcering som sosial praksis (s. 52-69). Oslo: Ad Notam Gyldendal.

Dreyfus, H. \& Dreyfus, S. (2012). Fem stadier av færdighedstilegnelse - fra nybegynder til ekspert. I K. Illeris (red.), 49 tekster om loering (s. 423-437). Fredriksberg: Samfundslitteratur.

Elmholdt, C. (2003). Kreativ læring er ikke nok. I K. Nielsen \& S. Kvale (red.): Praktikkens loeringslandskab - At loere gennem arbejde (s. 82-95). København: Akademisk Forlag. https://vbn.aau.dk/en/publications/kreativ-1\%C3\%A6ring-er-ikke-nok

Engvik, G. (2018). Læreres forståelser av utfordringer i praksisopplæring. En studie av eksamenstekster. Nordvei, 3(1), 44-58.

Engvik, G. \& Østern, A.-L. (2017). Utdanning av praksisveiledere ved NTNUs universitetsskoler i 2016. Rapport, NTNU. https://ntnuopen.ntnu.no/ntnu-

xmlui/bitstream/handle/11250/2466823/Rapport\%2B16.11.17.pdf?sequence=1\&isAllowe $\underline{\mathrm{d}=\mathrm{y}}$

Handal, G. \& Lauvås, P. (1983, 1999). På egne vilkår. En strategi for veiledning med loerere. Otta: J. W. Cappelens Forlag A/S.

Jacobsen, D. I. (2011). Hvordan gjennomføre undersøkelser? Kristiansand: Høyskoleforlaget. Jespersen, E. (1999). Idrettens kroppslige mesterlære. I K. Nielsen \& S. Kvale (red.), Mesterloere, loering som sosial praksis (s. 137-148). Oslo: Ad Notam Gyldendal.

Johannessen, A., Tufte, P. A. \& Christoffersen, L. (2016). Introduksjon til samfunnsvitenskapelig metode (4. utg.). Oslo: Abstrakt forlag.

Kemmis, S., Wilkinson, J., Edwards-Groves, C., Hardy, I., Grootenboer, P. \& Bristol, L. (2014). Changing Practices, Changing Education. Singapore: Springer.

Kvale, S. \& Nielsen, K. (1999). Landskap for læring. I K. Nielsen \& S. Kvale (red.), Mesterlaere, laering som sosial praksis (s. 196-214). Oslo: Ad Notam Gyldendal.

Kvale, S. \& Brinkmann, S. (2017). Det kvalitative forskningsintervju. Oslo: Gyldendal Akademisk.

Lave, J. (1999). Læring, mesterlære, sosial praksis. I K. Nielsen \& S. Kvale (red.), Mesterlaere, laering som sosial praksis (s. 37-52). Oslo: Ad Notam Gyldendal. 
Lave, J. \& Wenger, E. (1991). Situated learning - Legitimate peripheral participation. New York: Cambridge University Press.

Lave, J. \& Wenger, E. (2003). Situert loering og andre tekster. København: Hans Reitzels forlag.

Lave, J. \& Wenger, E. (2012). Situert læring - legitim perifer deltagelse. I K. Illeris (red.), 49 tekster om loering (s. 127-136). Fredriksberg: Samfundslitteratur.

Lejonberg, E. \& Føinum, M. (2018). Hva er god veiledning? Bergen: Fagbokforlaget.

Nielsen, K. (1999). Musikalsk mesterlære. I K. Nielsen \& S. Kvale (red.), Mesterlore, lcering som sosial praksis (s. 112-125). Oslo: Ad Notam Gyldendal.

Nielsen, K. \& Kvale, S. (1999a). Mesterlære som aktuell læringsform. I K. Nielsen \& S. Kvale (red.), Mesterloere, loering som sosial praksis (s. 17-33). Oslo: Ad Notam Gyldendal.

Nielsen, K. \& Kvale, S. (1999b). Ordforklaringer. I K. Nielsen \& S. Kvale (red.), Mesterloere, lcering som sosial praksis (s. 239-246). Oslo: Ad Notam Gyldendal.

Nilssen, V. (2018). Praksislcereren (2. utg.). Oslo: Universitetsforlaget.

Schön, D. A. (1988). Educating the reflective practitioner. San Francisco: Jossey-Bass.

Schön, D. A. (2012). Refleksion-i-handling. I K. Illeris (red.), 49 tekster om loering (s. 345358). Frederiksberg: Samfundslitteratur.

Skagen, K. (red.) (2000). Kunnskap og handling i pedagogisk veiledning. Bergen: Fagbokforlaget.

Skagen, K. (2013). I veiledningens landskap. Innføring $i$ veiledning og rådgivning (2. utgave). Oslo: Cappelen Damm.

Skagen, K. (2016). Kunnskapstyper og hegemonisk veiledningsstrategi i norsk veiledningsdiskurs. I A.-L. Østern \& G. Engvik (red.), Veiledningspraksiser i bevegelse (s. 59-77). Bergen: Fagbokforlaget.

Spurkeland, J. (2014). Relasjonskompetanse (2. utg.). Oslo: Universitetsforlaget.

Søndenå, K. (2009). Absolutt veiledning - om ontologisk kvalitet og elastisk refleksjon. I M. Brekke \& K. Søndenå (red.), Veiledningskvalitet (s. 17-29). Oslo: Universitetsforlaget.

Vygotskij, L. S. (1987). Problems of general psychology, including the volume Thinking and speech. New York: Plenum Press.

Wenger, E. (2004). Praksisfoellesskaber. København: Hans Reitzels Forlag.

Widén, P. (2017). Kvalitativ textanalys. I A. Fejes \& R. Thornberg (red.), Handbok $i$ kvalitativ ANALYS (s. 176-192) Stockholm: Liber as.

Worum, K.S. (2016). Spor av sammenhenger og brudd i kunnskapssyn i veiledning ved lærerutdanningen. Norsk pedagogisk tidsskrift, 100(02), 103-114. https://www.idunn.no/npt/2016/02/spor_av sammenhenger_ogbrudd i kunnskapssyn i veiledning_v 